E3S Web of Conferences 1, 13006 (2013)

DOI: $10.1051 / \mathrm{e} 3$ sconf/20130113006

(c) Owned by the authors, published by EDP Sciences, 2013

\title{
The Effect of Heavy Metal Contaminated Soil on Growth and Development of Perennial Grasses
}

\author{
G. Żurek $^{1}$, M. Pogrzeba ${ }^{2}$, K. Rybka ${ }^{3}$, J. Krzyżak ${ }^{4}$ and K. Prokopiuk ${ }^{5}$
}

${ }^{1}$ Department of Grasses, Legumes and Energy Plants, Plant Breeding and Acclimatization Institute, National Research Institute, Radzików, Poland, g.zurek@ihar.edu.pl

${ }^{2}$ Department of Environmental Biotechnology, Phytoremediation Team, Institute for Ecology of Industrial Areas, Katowice, Poland, mag@ietu.katowice.pl

${ }^{3}$ Department of Plant Physiology and Biochemistry, Plant Breeding and Acclimatization Institute, National Research Institute, Radzików, Poland, k.rybka@ihar.edu.pl

${ }^{4}$ Department of Environmental Biotechnology, Phytoremediation Team, Institute for Ecology of Industrial Areas, Katowice, Poland, jkrzyzak@ietu.katowice.pl

${ }^{5}$ Department of Grasses, Legumes and Energy Plants, Plant Breeding and Acclimatization Institute, National Research Institute, Radzików, Poland, k.prokopiuk@ihar.edu.pl

\begin{abstract}
Contamination of agricultural land in Poland by heavy metals is not a general problem but is limited to industrial areas. In regions of long history of industrial emission, of elevated levels of lead, cadmium, zinc and other ions during coal and ore mining and processing, as for example in Silesia, about $10 \%$ of agricultural land may be characterized by exceeded maximum residue limits for $\mathrm{Cd}, \mathrm{Pb}, \mathrm{Cu}, \mathrm{Ni}$ and $\mathrm{Zn}$ ions. Since the maintenance of agricultural areas in those regions is important from an ecological standpoint, the alternative farming activities are needed. Perennial grass biomass production for energy purposes is currently the best solution for majority of agricultural areas not suitable for food production in Poland. Along with increasing knowledge on separation and utilization of heavy metals (HM) during and after biomass processing, phytoremediation of polluted soils will become important and valuable. To detect the effect of soil HM ions concentration on growth and development of selected, tall growing and high biomass yielding perennial grass cultivars, the chlorophyll fluorescence parameters were registered. The elevated content of $\mathrm{Pb}, \mathrm{Cd}$ and $\mathrm{Zn}$ ions in soil influenced on decrease of: minimal $\left(\mathrm{F}_{\mathrm{o}}\right)$, maximal $\left(\mathrm{F}_{\mathrm{m}}\right)$ and variable $\left(\mathrm{F}_{\mathrm{v}}\right)$ fluorescence level as well as on total complementary area on a diagram of chlorophyll $a$ fluorescence induction curve (Area). Based on detected parameters it was concluded, that the high level of HM ions in soils negatively affected the efficiency of photosynthesis. Therefore, plant growth, as well as development of generative shoots and finally the biomass yield were reduced in some cultivars. Among tested cultivars different reaction for HM ions in polluted soil were noted: from only slightly modified parameters of photosynthesis and unreduced yield (Elytrigia elongata cv. Bamar and Arrhenatherum elatius cv. Wiwena) to significantly reduced $\mathrm{F}_{\mathrm{o}}, \mathrm{F}_{\mathrm{v}}, \mathrm{F}_{\mathrm{m}}$ and biomass yield (Bromus carinathus cv. Broma and Bromus inermis cv. Brudzyńska).
\end{abstract}

Keywords: biomass, phytoremediation, tall wheat grass, brome grass, tall fescue

\section{Introduction}

The toxicity of heavy metals is apparent in reducing growth and development of plants, and seriously harming the health of animals and humans (Kvesitadze et al. 2006). Plant development and growth is always closely related to the stability and functionality of basic energy source for plants which is photosynthesis. Therefore, disorders in photosynthesis may result in reduction of growth, biomass or generative reproduction. HM ions inhibit multiple metabolic processes in plants which are manifested by changes in many chlorophyll $a$ fluorescence parameters (Joshi and Mohanty, 2010). Some metals such as $\mathrm{Hg}, \mathrm{Cu}, \mathrm{Cd}, \mathrm{Ni}$ or $\mathrm{Zn}$ may substitute the central $\mathrm{Mg}$ in chlorophyll molecule, consequently lowering PSII quantum efficiency. Therefore, the formation of these chlorophyll-metal ions complexes is leading to a loss in efficiency in conversion of light energy into photochemical reaction (Popovic et al. 2003). The 
influence of particular HM ion on plant physiology may be different but in the case of naturally polluted soils, all contaminants act synergistically so only cumulative effect of their influence is possible to be detected. Our experiment was performed using polluted soil from urbanized region of Poland, recognized previously as having the excess amounts of $\mathrm{Pb}, \mathrm{Cd}$, and $\mathrm{Zn}$ ions (Pogrzeba et al. 2010). The experiment was undertaken to study the effect of the concentration of soil HM ions on the growth and development of some perennial grass cultivars. The acquired knowledge is to be used in planning of biomass processing systems and, in parallel, in of phytoremediation of polluted soils, using cultivation of energy plants as a main concept.

\section{Materials and Methods}

The experiment was located on contaminated agricultural soil in Bytom (southern part of Poland, Silesia). Plots were established in the vicinity of a closed-down lead/zinc/cadmium ore mining and processing plant, which operated for more than 100 years and had significant impact on local soils. Reference site (uncontaminated soil) was located in a distance from above on agricultural land with similar fore crop history. Five perennial grass cultivars: Festuca arundinacea (Fa.) cv. Rahela, Arrhentherum elatius (Ae.) cv. Wiwena, Elytrigia elongata (Ee.) cv. Bamar, Bromus inermis (Bi.) cv. Brudzyński and Bromus carinathus $(\mathrm{Bc}$.) cv. Broma were sown at the end of June 2010 on 1 x $1 \mathrm{~m}$ plots, with 3 replications per variety. No further treatments (i.e. fertilization, herbicides, watering etc.) were applied, despite of aboveground biomass cutting and collecting at the end of growing seasons in 2010 and 2011. All observations and measurements were done in 2011; plant height (PH, $\mathrm{cm})$, generative shoots abundance (GS, \% of plot area) and chlorophyll (Chl) fluorescence parameters $\left(\mathbf{F}_{\mathbf{o}}, \mathbf{F}_{\mathbf{m}}\right.$, $\mathbf{F}_{\mathbf{v}}$ and Area, measured with Pocket Pea, Hansatech Instr., after $20 \mathrm{~min}$. of dark-adaptation) in June and biomass yield (BY, t/ha) in October. Total $\mathrm{Pb}, \mathrm{Cd}$ and $\mathrm{Zn}$ concentration in plant tissues $\left(\mathrm{mg} \cdot \mathrm{kg}^{-1}\right)$ were estimated in dried biomass collected in October 2011, by Regional Agro-Chemical Station.

\section{Results and Discussion}

Physical and chemical soil properties from both locations are presented in Table 1.

Heavy metals concentration in polluted soil exceeded Polish limits for arable soil of $304.5 \mathrm{mg} \cdot \mathrm{kg}^{-1}$ for $\mathrm{Pb}, 12.7 \mathrm{mg} \cdot \mathrm{kg}^{-1}$ for $\mathrm{Cd}$ and of $1677.5 \mathrm{mg} \cdot \mathrm{kg}^{-1}$ for $\mathrm{Zn}$. Soils used in our experiment were similar in $\mathrm{pH}$ value, organic matter contents and different in clay and sand amounts.

Elevated concentration of $\mathrm{Pb}, \mathrm{Cd}$ and $\mathrm{Zn}$ in soil affected photosynthetic activity of the majority of tested grass cultivars and it was reflected by the decrease of $\mathrm{F}_{\mathrm{o}}, \mathrm{F}_{\mathrm{v}}, \mathrm{F}_{\mathrm{m}}$ and Area (Table 2).
Tab.1 The soil characteristics

\begin{tabular}{lcc}
\hline \multicolumn{1}{c}{ Soil properties } & \multicolumn{2}{c}{ Location: } \\
\cline { 2 - 3 } & contaminated & reference \\
\hline pH (in KCl) & 6.8 & 6.1 \\
org. matter $(\%)$ & 4.0 & 3.5 \\
sand (\%) & 28 & 45 \\
silt $(\%)$ & 56 & 51 \\
clay $(\%)$ & 16 & 5 \\
$\mathrm{~Pb}\left(\mathrm{mg} \mathrm{kg}^{-1}\right)$ & 404.5 & 7.65 \\
$\mathrm{Cd}\left(\mathrm{mg} \mathrm{kg}^{-1}\right)$ & 16.7 & 0.16 \\
$\mathrm{Zn}\left(\mathrm{mg} \mathrm{kg}^{-1}\right)$ & 1977.5 & 17.7
\end{tabular}

Tab.2 Results of measurements taken on grass cultivars tested in our experiment

\begin{tabular}{|c|c|c|c|c|}
\hline \multirow{2}{*}{$\begin{array}{l}\text { Species } \\
\text { and } \\
\text { cv name }\end{array}$} & \multirow{2}{*}{ Trait } & \multicolumn{2}{|c|}{ Site type: } & \multirow{2}{*}{$\begin{array}{l}\text { Signif. } \\
\text { of differ. }\end{array}$} \\
\hline & & polluted & reference & \\
\hline \multirow{7}{*}{$\begin{array}{l}\text { Ae. } \\
\text { Wiwena }\end{array}$} & $\mathrm{F}_{\mathrm{o}}$ & 4970.7 & 6135.0 & n.s. \\
\hline & $\mathrm{F}_{\mathrm{v}}$ & 26775.0 & 31680.5 & n.s. \\
\hline & $\mathrm{F}_{\mathrm{m}}$ & 21804.3 & 25545.5 & n.s. \\
\hline & Area & 699791.0 & 977466.5 & $* *$ \\
\hline & $\mathrm{PH}$ & 65.8 & 83.3 & n.s. \\
\hline & GS & 8.3 & 18.3 & $* *$ \\
\hline & BY & 3.7 & 4.3 & n.s. \\
\hline \multirow{7}{*}{$\begin{array}{l}\text { Bi. } \\
\text { Bru- } \\
\text { dzynska }\end{array}$} & $\mathrm{F}_{\mathrm{o}}$ & 4872.0 & 6752.3 & n.s. \\
\hline & $\mathrm{F}_{\mathrm{v}}$ & 24186.0 & 33058.0 & $* *$ \\
\hline & $\mathrm{F}_{\mathrm{m}}$ & 19314.0 & 26305.7 & $* *$ \\
\hline & Area & 500814.3 & 881704.3 & $* *$ \\
\hline & $\mathrm{PH}$ & 81.3 & 90.7 & n.s. \\
\hline & GS & 15.0 & 16.7 & n.s. \\
\hline & $\mathrm{BY}$ & 1.8 & 4.0 & $* * *$ \\
\hline$B c$. & $\mathrm{F}_{\mathrm{o}}$ & 4518.3 & 6734.3 & $* *$ \\
\hline \multirow[t]{6}{*}{ Broma } & $\mathrm{F}_{\mathrm{v}}$ & 23035.7 & 31087.3 & $* * *$ \\
\hline & $\mathrm{F}_{\mathrm{m}}$ & 18517.3 & 24353.0 & $* *$ \\
\hline & Area & 421786.0 & 560246.0 & n.s. \\
\hline & $\mathrm{PH}$ & 72.0 & 72.8 & n.s. \\
\hline & GS & 86.7 & 90.0 & n.s. \\
\hline & BY & 1.7 & 2.8 & $* *$ \\
\hline F.a. & $\mathrm{F}_{\mathrm{o}}$ & 4545.0 & 5911.0 & n.s. \\
\hline \multirow[t]{6}{*}{ Rahela } & $\mathrm{F}_{\mathrm{v}}$ & 19489.7 & 27972.3 & $* *$ \\
\hline & $\mathrm{F}_{\mathrm{m}}$ & 14944.7 & 22061.3 & $* *$ \\
\hline & Area & 307912.7 & 638960.3 & $* *$ \\
\hline & $\mathrm{PH}$ & 62.7 & 72.6 & n.s. \\
\hline & GS & 9.0 & 26.7 & $* *$ \\
\hline & BY & 3.7 & 4.3 & n.s. \\
\hline E.e. & $\mathrm{F}_{\mathrm{o}}$ & 3868.7 & 5922.7 & n.s. \\
\hline \multirow[t]{6}{*}{ Bamar } & $F_{v}$ & 20008.3 & 31408.0 & n.s. \\
\hline & $\mathrm{F}_{\mathrm{m}}$ & 16139.7 & 25485.3 & n.s. \\
\hline & Area & 465325.0 & 1132291.0 & $* *$ \\
\hline & $\mathrm{PH}$ & 49.9 & 54.4 & n.s. \\
\hline & GS & 1.0 & 1.3 & n.s. \\
\hline & BY & 2.0 & 1.7 & n.s. \\
\hline
\end{tabular}

Explanation for significance of difference: n.s. - not significant, significant with probability: $* *-\mathrm{P}>95 \%$, $* * *$ - $\mathrm{P}>99 \%$ 
As a consequence, GS and BY were affected in few cultivars. Cultivars: Wiwena and Rahela produced less generative shoots and Broma and Brudzyńska yielded less when grown on polluted soil. Cultivar Bamar exposed no statistically significant effect of polluted soil on growth and development, and it was associated with only minor effect on Chl fluorescence parameters. The general physiological effects of HM ions result from their ability to disrupt disulfide links in proteins and from the substitution of essential ions (Joshi and Mohanty 2010). In general, HM lower photosynthetic rates, affecting both light and dark reactions. At relatively high concentrations, $\mathrm{HM}$ ions lower $\mathrm{F}_{\mathrm{o}}$ and this change is attributed to a metal ion dependent structural change in LHC II or a non-specific chlorophyll excited state quenching by metal ions (Joshi and Mohanty 2010). In our experiment we have noted statistically significant decrease of $F_{o}$ in case of cv. Broma, with concomitant reduction of $\mathrm{F}_{\mathrm{m}}$ and $\mathrm{F}_{\mathrm{v}}$. In vitro experiments on the treatment of tylakoids with $\mathrm{HM}$ resulted in decreased $\mathrm{F}_{\mathrm{m}}$ values, and it was caused by decrease in $\mathrm{F}_{\mathrm{v}}$ (Arellano et al. 1995).

Among all tested Chl fluorescence parameters, Area was most frequently reduced in plants grown on polluted soil. Mentioned parameter was reported to be reduced in the presence of stress factors, when the electron transport from reaction centers to plastoquinone was inhibited (Kalaji and Łoboda, 2010). Therefore, our results partly suggest the possibility of the alterations of photosynthetic electron transport by heavy metal ions in grass plants grown on HM polluted soil.

The threshold of metal ion toxicity seem to be specific to the metal and the plant. It has been concluded from comparative studies of the effect on $\mathrm{Cu}$, $\mathrm{Cd}, \mathrm{Pb}$ and $\mathrm{Zn}$ on photosynthetic response of plant that $\mathrm{Cu}$ and $\mathrm{Zn}$ are significantly more toxic than $\mathrm{Pb}$ and $\mathrm{Cd}$ (Ralph and Burchet, 1998). Moreover, the action of metal ions on plants is modulated by other metal ions and the nature of this interaction seems to be complex (Joshi and Mohanty 2010).

Tested cultivars exposed different ability to absorb HM from soil (Table 3).

The highest values of $\mathrm{Cd}$ and $\mathrm{Zn}$ were found in the biomass of cv. Rahela (8.5 and $417 \mathrm{mg} \cdot \mathrm{kg}^{-1}$, respectively). High $\mathrm{Zn}$ accumulation of Festuca arundinacea cv. K-31 was reported by Palazzo et al. (2003). What should be mentioned here is that high accumulation of $\mathrm{Zn}$ and $\mathrm{Cd}$ was not associated with yield reduction of cv. Rahela.

\section{Conclusions}

1. The combined effects of elevated concentration lead, cadmium and zinc in soil was manifested in alteration of chlorophyll fluorescence parameters (minimal, maximal and variable fluorescence) and in photosynthetic electron transport.
2. Heavy metal contamination of soil influenced on biomass yield reduction of cultivars from Bromus inermis and B. carinathus.

3. Some species, as Festuca arundinacea, may absorb relatively high amounts of HM ions from the soil, without significant reduction of biomass yield, what is expected in the case of bioremediation practices.

Tab.3 Concentration of HM in plant biomass

\begin{tabular}{lcccc}
\hline \multirow{2}{*}{$\begin{array}{l}\text { Species and } \\
\text { cv name }\end{array}$} & $\begin{array}{c}\text { Soil } \\
\text { type: }\end{array}$ & \multicolumn{3}{c}{$\mathrm{Pb}$ uptake $\left(\mathrm{mg} \cdot \mathrm{kg}^{-1}\right)$} \\
\cline { 3 - 5 } A.e. & pol. & 64.0 & 3.0 & 185.5 \\
Wiwena & ref. & 0.31 & 0.10 & 20.45 \\
\hline B.i. & pol. & 59.5 & 3.4 & 256.0 \\
Brudzyńska & ref. & 0.37 & 0.18 & 25.25 \\
\hline B.u. & pol. & 51.0 & 2.2 & 197.0 \\
Broma & ref. & 0.35 & 0.08 & 16.7 \\
\hline F.a. & pol. & 50.0 & 8.5 & 417.0 \\
Rahela & ref. & 0.73 & 0.19 & 19.5 \\
\hline E.e. & pol. & 31.0 & 2.2 & 253.0 \\
Bamar & ref. & 0.25 & 0.14 & 18.45 \\
\hline LSD & pol. & n.s. & 1.33 & 113.5 \\
(P>95\%) & ref. & n.s. & n.s. & n.s. \\
\hline Explantion & pollted & ref. & &
\end{tabular}

Explanation: pol. - polluted, ref. - reference

\section{References}

Arellano JB, Lazaro JJ, Lopez-Gorge J, Baron M. The donor side of Photosystem II as a copperinhibitory binding site. Photosynthesis Research 1995; 45: 127 - 134.

Joshi MK, Mohanty P. 2010. Chlorophyll a fluorescence as a probe of heavy metal ion toxicity in plants. In: Papageorgiou G.C., Govindjee (eds) Chlorophyll a Fluorescence: A Signature of Photosynthesis, Springer Science + Business Media B.V., 2010, p. $637-661$.

Kalaji MH, Łoboda T. Fluorescencja chlorofilu w badaniach stanu fizjologicznego roślin. Warszawa: Wydawnictwo SGGW; 2010.

Kvesitadze G, Khatisashvili G, Sadunishvili T, Ramsden JJ. Biochemical Mechanisms of Detoxification in Higher Plants. Berlin Haidelberg: Springer Verlag; 2006.

Palazzo AJ, Cary TJ, Hardy SE, Lee RC. Root growth and metal uptake in four grasses grown on zinccontaminated soils. Journal of Environmental Quality 2003; 32: $834-840$.

Pogrzeba M, Krzyżak J, Sas-Nowosielska A. How to grow energy crop on heavy metal contaminated soil. Proceedings of 15th International Conference on Heavy Metals in the Environment, 2010; 676679.

Popovic R, Dewez D, Juneau P. Applications of chlorophyll fluorescence in ecotoxicology: heavy metals, herbicides, and air pollutants. In: DeEll JR, 
Toivonen PMA. (eds) Practical Application of Chlorophyll Fluorescence in Plant Biology. Norwell, MS, USA: Kluwer Academic Publishers; 2003. p. $151-184$.

Ralph PJ, Burchett MD. Photosynthetic response of Halophila ovalis to heavy metal stress. Environmental Pollution 1998; 103: 91 -101.
Strasser RJ, Tsimili - Michael M, Srivastava A. Analysis of the chlorophyll a fluorescence transient. In: Papageorgiou G.C., Govindjee (eds) Chlorophyll $a$ Fluorescence: A Signature of Photosynthesis, Springer Science + Business Media B.V.; 2010; p. $321-362$. 